\title{
Characterization of cereal cyst nematodes (Heterodera spp.) in Morocco based on morphology, morphometrics and rDNA-ITS sequence analysis
}

\author{
Fouad Mokrini ${ }^{1 *}$, Nicole Viaene ${ }^{2,3}$, Lieven Waeyenberge ${ }^{2}$, \\ Abdelfattah A. Dababat ${ }^{5}$, Maurice Moens ${ }^{2,4}$ \\ ${ }^{1}$ National Institute for Agricultural Research (INRA), Agadir, Morocco \\ ${ }^{2}$ Institute for Agricultural and Fisheries Research, Plant, Crop Protection, Burg. Van Gansberghelaan 96, \\ B-9820 Merelbeke, Belgium \\ ${ }^{3}$ Department of Biology, Ghent University, K.L. Ledeganckstraat 35, B-9000 Ghent, Belgium \\ ${ }^{4}$ Faculty of Bio-science Engineering, Ghent University, Coupure links 653, B-9000 Ghent, Belgium \\ ${ }^{5}$ CIMMYT (International Maize and Wheat Improvement Centre) P.K. 39 06511, Emek, Ankara, Turkey
}

Vol. 57, No. 3: 219-227, 2017

DOI: 10.1515/jppr-2017-0031

Received: April 22, 2017

Accepted: June 18, 2017

${ }^{*}$ Corresponding address:

fmokrini.inra@gmail.com

\begin{abstract}
Morphological and molecular diversity among 11 populations of cereal cyst nematodes from different wheat production areas in Morocco was investigated using light microscopy, species-specific primers, complemented by the ITS-rDNA sequences. Morphometrics of cysts and second-stage juveniles (J2s) were generally within the expected ranges for Heterodera avenae; only the isolate from Ain Jmaa showed morphometrics conforming to those of $H$. latipons. When using species-specific primers for $H$. avenae and $H$. latipons, the specific bands of $109 \mathrm{bp}$ and $204 \mathrm{bp}$, respectively, confirmed the morphological identification. In addition, the internal transcribed spacer (ITS) regions were sequenced to study the diversity of the 11 populations. These sequences were compared with those of Heterodera species available in the GenBank database (www.ncbi.nlm.nih.gov) and confirmed again the identity of the species. Ten sequences of the ITS-rDNA were similar (99-100\%) to the sequences of $H$. avenae published in GenBank and three sequences, corresponding with one population, were similar (97-99\%) to H. latipons.
\end{abstract}

Key words: Heterodera avenae, Heterodera latipons, molecular

\section{Introduction}

Cereal cyst nematodes (CCN) form a group of several closely related species. Three species (Heterodera avenae, $H$. filipjevi and H. latipons) are among the economically most important cyst nematode pests of cultivated cereals (Smiley and Nicol 2009). Heterodera avenae is widely distributed in temperate wheat-producing regions throughout the world (Smiley and Nicol 2009). Heterodera latipons is found in the Mediterranean regions, eastern and northern Europe, the Middle and Near East, North and South Africa, Asia and North America (Greco et al. 2002; Abidou et al. 2005; Smiley and Nicol 2009), whilst $H$. filipjevi has been reported from eastern and northern Europe, Central and West Asia, the Middle East, the Indian subcontinent and North America (Rumpenhorst et al. 1996; Rivoal et al. 2003; Holgado et al. 2004). Earlier reports from Morocco mention only $H$. avenae as representative of the CCN. The nematode was detected for the first time in 1951 in an irrigated wheat (T. aestivum) field in the Gharb region (Ritter 1982). More populations of $H$. avenae were found during later surveys (Ammati 1987; Mokrini et al. 2009). In all of these Moroccan studies, cysts were identified using only morphological features; morphometrical and molecular identification were not considered. 
The taxonomy of the $H$. avenae group and its members has been the object of several review papers (Ferris et al. 1994; Handoo 2002). Species belonging to this group form a complex, and invade and reproduce only in roots of cereals and grasses (Subbotin et al. 1999). Within the $H$. avenae group, only minor morphological and morphometrical differences distinguish the species from each other (Subbotin et al. 1999). The increasing number of species in this group makes morphological and morphometrical identification more difficult because it is time consuming and requires appropriate skills (Subbotin et al. 2003). Nevertheless, accurate identification of members of the $H$. avenae group is needed as an initial step in designing effective control measures. This is especially important when searching for potential sources of host-plant resistance against Heterodera species (Dababat et al. 2015). Furthermore, rapid and accurate identification is highly significant for quarantine purposes. For these reasons, the development of molecular methods to identify members of the $H$. avenae group has been the goal of numerous studies. The internal transcribed spacer regions of ribosomal genes (ITS-rDNA) were found to be useful to differentiate species within the $H$. avenae group (Subbotin et al. 2000; Zheng et al. 2000). Additionally, the comparison of sequences of the ITS-rDNA region of unknown species with those published and deposited in GenBank has facilitated fast identification of most species of cyst-forming nematodes (Subbotin et al. 1999, 2000).

Because Moroccan CCN have mainly been identified on the basis of their morphology very little information is available on the diversity and variability of their morphometrics and genetics. Only Subbotin et al. (2003) published three sequences of $H$. avenae from Morocco. To fill these gaps, we conducted a survey in the major wheat growing areas in Morocco with the following main objectives: (a) to collect, identify and compare both cysts and second-stage juveniles (J2s) of populations of CCN using morphological, morphometrical and molecular approaches including species-specific polymerase chain reaction (PCR) and sequencing of the ITS-rDNA expansion segments, and (b) to determine the phylogenetic relationships between these populations.

\section{Materials and Methods}

\section{Collection of populations of the Heterodera avenae group}

Sampling was carried out during the wheat-growing season (May to June 2011) in four different regions representing the main wheat growing areas of Morocco. Soil and root samples were taken from 75 cereal fields. Sixty-nine samples were taken from wheat fields; the remaining six samples were obtained from barley fields. Samples were taken where wheat or barley plants showed chlorotic, yellowing leaves and poor growth. Each sample (soil and root) was composed of 15 subsamples randomly collected per field. Cysts were extracted from each soil sample using the modified Cobb decanting and sieving method (Cobb 1918). After extraction, cysts were stored at $4^{\circ} \mathrm{C}$.

\section{Morphology and morphometrics of populations}

Species identification was based on cyst vulval cone structures and measurements, as well as morphometric features of the J2s. The vulval cone of the cysts was cut and prepared for microscopic examination according to Hooper (1986). For each population, cones of 10 mature cysts were mounted in glycerine jelly. For each population, juveniles were obtained from the same cysts, killed by gentle heat (warming up enough to kill the nematode but not too long not to deform or destroy it), fixed in triethanolamine formalin solution (TAF), embedded in glycerol; permanent slides were made immediately. Ten J2s of the selected cyst populations were examined and measured using an Olympus BX51 compound microscope.

\section{Molecular characterization}

\section{DNA extraction}

For each population, a single J2 isolated from a single cyst was transferred into an Eppendorf tube containing $25 \mu$ double distilled water $\left(\mathrm{ddH}_{2} \mathrm{O}\right)$ and $25 \mu \mathrm{l}$ nematode lysis buffer [final concentration: $200 \mathrm{mM} \mathrm{NaCl}, 200 \mathrm{mM}$ Tris- $\mathrm{HCl}$ (pH 8), 1\% mercaptoethanol and $800 \mu \mathrm{g}$ Proteinase $\mathrm{K}]$. The tubes were incubated at $65^{\circ} \mathrm{C}$ for $1.5 \mathrm{~h}$ and at $99^{\circ} \mathrm{C}$ for $5 \mathrm{~min}$, consecutively (Holterman et al. 2006). The extracted DNA suspension was stored at $-20^{\circ} \mathrm{C}$ or used immediately for DNA amplification.

\section{PCR with species-specific primers}

The species-specific primers set AVEN-COI-forward (5'-GGG TTT TCG GTT ATT TGG-3') and AVENCOI-reverse (5'-CGC CTA TCT AAA TCT ATA CCA-3') (Toumi et al. 2013a) together with the universal primers developed by Ferris et al. (1993), i.e. forward primer 5'-CGT AAC AAG GTA GCT GTA G-3' and the reverse primer 5'-TCC TCC GCT AAA TGA TAT G-3', were used to detect $H$. avenae in the DNA extracts of 11 populations. Extracts that were not identified as belonging to $H$. avenae were used in a PCR with the species-specific primers set Hla-acti-F (5'-ACT TCA TGA TCG AGT TGT AGG TGG ACT CG-3') and Hla-acti-F (5'-ACC TCA CTG ACT ACC GAT GAA GAT TC-3') (Toumi et al. 2013b) along 
with the universal reverse primers (Ferris et al. 1993) to eventually characterise $H$. latipons.

The PCR used to detect $H$. avenae was run as follows: $2 \mu \mathrm{DNA}$ extract (see above) were added to the PCR reaction mixture containing $21 \mu \mathrm{lddH_{2 }} O, 25 \mu \mathrm{l} 2 \times$ DreamTaq PCR Master Mix (Fermentas Life Sciences, Germany) and $1 \mu \mathrm{M}$ of each of the primers AVEN-COI (Toumi et al. 2013a) and Ferris et al. (1993). The thermal cycler programme consisted of $5 \mathrm{~min}$ at $95^{\circ} \mathrm{C}, 30$ cycles of $30 \mathrm{~s}$ at $94^{\circ} \mathrm{C}, 30 \mathrm{~s}$ at $58^{\circ} \mathrm{C}$ and $45 \mathrm{~s}$ at $72^{\circ} \mathrm{C}$, followed by a final elongation step of $8 \mathrm{~min}$ at $72^{\circ} \mathrm{C}$. For the detection of $H$. latipons, $2 \mu \mathrm{l}$ of the DNA extract was added to the PCR reaction mixture containing $21 \mu \mathrm{lddH_{2 }} \mathrm{O}, 25 \mu \mathrm{l} 2 \times$ DreamTaq PCR Master Mix (Fermentas Life Sciences, Germany), and $1 \mu \mathrm{M}$ of each of the primers Hla-acti (Toumi et al. 2013b) and Ferris et al. (1993). The programme of the thermal cycler consisted of $5 \mathrm{~min}$ at $95^{\circ} \mathrm{C} ; 50$ cycles of $30 \mathrm{~s}$ at $94^{\circ} \mathrm{C}, 45 \mathrm{~s}$ at $50^{\circ} \mathrm{C}$ and $45 \mathrm{~s}$ at $72^{\circ} \mathrm{C}$, followed by a final elongation step of $8 \mathrm{~min}$ at $72^{\circ} \mathrm{C}$.

\section{Amplification, sequencing} and phylogenetic analysis

The ITS-rDNA region was amplified using the primers 5'-CGT AAC AAG GTA GCT GTA G-3' and 5'TCC TCC GCT AAA TGA TAT G-3' (Ferris et al. 1993). The purification process was done as described by the manufacturer's instructions (Wizard ${ }^{\circledR}$ SV Gel and PCR Clean-Up System Kit, Promega). DNA from each sample was sequenced (Macrogen, Seoul, South Korea) in both directions to obtain overlapping sequences of both DNA strands. The sequences were edited and analysed using software packages Chromas 2.00 (Technelysium, Helensvale, QLD, Australia) and BioEdit 7.0.4.1 (Hall 1999). Finally, all sequences were blasted in GenBank (Sequin v. 9.00, http://www.ncbi. nlm.nih.gov/). Twenty-nine ITS sequences of $H$. avenae and $H$. latipons (13 new and 16 from GenBank) were aligned using Clustal W (Thompson et al. 1994) and visually checked. Differences between sequences were estimated using the DNA distance option provided by BioEdit sequence alignment editor (Hall 1999). The alignment was imported into the software package Mega 5.0; after checking 24 different nucleotide substitution models, the model with the lowest BIC score (Bayesian Information Criterion) was retained for constructing a $60 \%$ consensus Neighbour-joining tree. To determine statistical consistency of the classification, bootstrap analysis using 1,000 bootstrapped data sets was performed.

\section{Results}

\section{Morphology and morphometrics}

The survey yielded 11 Heterodera populations (Table 1). Ten populations were monospecific for $H$. avenae and one for H. latipons.

\section{Heterodera avenae (Wollenweber, 1924) \\ Cysts}

Mostly lemon-shaped, with a protruding neck and vulvar cone. Cyst wall - dark brown, bearing a zig-

Table 1. Species and populations of Heterodera collected during a survey in wheat producing areas of Morocco

\begin{tabular}{|c|c|c|c|c|c|c|c|}
\hline \multirow{2}{*}{ Code } & \multirow{2}{*}{ Location } & \multirow{2}{*}{ Area } & \multirow{2}{*}{ Host } & \multirow{2}{*}{$\begin{array}{l}\text { Morphological } \\
\text { identification }\end{array}$} & \multicolumn{2}{|c|}{ Identification using PCR } & \multirow{2}{*}{$\begin{array}{c}\text { Result } \\
\text { of sequencing }\end{array}$} \\
\hline & & & & & H. avenae & H. latipons & \\
\hline $\mathrm{H} 01$ & Haj Kaddor & Saiss & DW & + & + & - & $\mathrm{Ha}$ \\
\hline $\mathrm{H} 02$ & Ait Malk & Saiss & w & + & + & - & $\mathrm{Ha}$ \\
\hline $\mathrm{H} 03$ & Ain Taoujdtae & Saiss & DW & + & + & - & $\mathrm{Ha}$ \\
\hline $\mathrm{H} 04$ & Ain Jmaa & Saiss & DW & + & - & + & $\mathrm{HI}$ \\
\hline $\mathrm{H} 05$ & Marrakech & Zaers & $w$ & + & + & - & $\mathrm{Ha}$ \\
\hline $\mathrm{H} 06$ & Marchouch & Zaers & DW & + & + & - & $\mathrm{Ha}$ \\
\hline $\mathrm{H} 07$ & Marchouch & Zaers & DW & + & + & - & $\mathrm{Ha}$ \\
\hline $\mathrm{H} 08$ & Mediona & Chaouia & w & + & + & - & $\mathrm{Ha}$ \\
\hline $\mathrm{H} 09$ & Berchd & Chaouia & w & + & + & - & $\mathrm{Ha}$ \\
\hline $\mathrm{H} 10$ & Settat & Chaouia & DW & + & + & - & $\mathrm{Ha}$ \\
\hline $\mathrm{H} 11$ & Settat & Chaouia & DW & + & + & - & $\mathrm{Ha}$ \\
\hline
\end{tabular}

' + ' positive for the mentioned species

'-' negative for the mentioned species 
zag pattern. Vulval cone bifenestrate. No underbridge. Bullae in all populations. The cyst of populations $\mathrm{H} 01$, H03, H07 and H08 - slightly bigger than other populations (Table 2).

\section{Second-stage juveniles}

Body - cylindrical, head - slightly offset, tapering round tail tip. Stylet - strong with shallow anteriorly concave basal knobs. Body length - 503 to $640 \mu \mathrm{m}$; stylet length - 22.3-27.9 $\mu \mathrm{m}$; anteriorly concave basal knobs. Lateral field with four incisures (Table 3 ).

\section{Remarks}

This species was detected in 10 populations ( $\mathrm{H} 01, \mathrm{H} 02$, H03, H05, H06, H07, H08, H09, H10, H11). These populations were morphologically and morphometrically similar to populations described previously (Handoo 2002; Subbotin et al. 2003).

\section{Heterodera latipons (Franklin, 1969) Cysts}

The cysts $(n=10)$ had the following characteristics: lemon-shaped; cyst wall partially transparent, between light and dark brown; ridges with zigzag pattern. Bifenestrate vulval cone, body length without neck $590 \mu \mathrm{m}$ ( 551 to $632 \mu \mathrm{m})$, body width $-393 \mu \mathrm{m}$ (310 to $490 \mu \mathrm{m})$, neck length - $75 \mu \mathrm{m}(65$ to $90 \mu \mathrm{m})$, fenestra length $-64 \mu \mathrm{m}(60$ to $72 \mu \mathrm{m})$ and width $21 \mu \mathrm{m}$ (18 to $25 \mu \mathrm{m})$, underbridge length $-96 \mu \mathrm{m}$ (85 to $115 \mu \mathrm{m})$, vulval slit length $-8 \mu \mathrm{m}$ (7 to $9 \mu \mathrm{m})$, vulva bridge width $-27 \mu \mathrm{m}(24$ to $33 \mu \mathrm{m})$, and bullae absent. The bifenestrate cysts with a strong underbridge and no bullae.

\section{Second-stage juveniles}

The J2s $(n=10)$ had the following characteristics: cylindrical head slightly offset, round tail tip tapering. Compared with $H$. avenae bodies - slightly shorter and short hyaline terminal tail. Body length - $445 \mu \mathrm{m}$ (412 to $472 \mu \mathrm{m})$, body width - $19 \mu \mathrm{m}$ (19 to $21 \mu \mathrm{m})$, stylet length $-24 \mu \mathrm{m}$ ( 23 to $25 \mu \mathrm{m}$ ), four lateral lines, tail length - $50 \mu \mathrm{m}$ ( 46 to $54 \mu \mathrm{m}$ ), and hyaline terminal tail $-28 \mu \mathrm{m}(24$ to $31 \mu \mathrm{m})$.

\section{Remarks}

Only one population of $H$. latipons was detected (Ain Jmaa, Saiss). The morphometrics and morphological characters corresponded to those reported by Handoo (2002).

\section{Molecular characterization}

\section{Species-specific PCR and sequencing}

The H. avenae-specific primers PCR (AVEN-COI) amplified a band of $109 \mathrm{bp}$ for 10 samples (H01, H02, H03, H05, H06, H07, H08, H09, H10 and H11) (Fig. 1). This means that out of 11 populations, 10 populations were molecularly identified as $H$. avenae. For the sample (one population) not identified as $H$. avenae, the $H$. latipons-specific primers (Hlat-act) amplified a specific band of $204 \mathrm{bp}$.

\section{ITS sequence and analysis}

A comparison of ITS-rDNA sequences of $H$. avenae and $H$. latipons populations among themselves and with sequences of Heterodera species available in GenBank is presented in Figure 2. The comparison confirmed the identification of the species using morphological features and species-specific PCR. Ten sequences of the ITS-rDNA were similar (99-100\%) to the sequences of $H$. avenae published in GenBank (AY148363, AY148364, AY148360, AY148359, AY148361, AY148362, AY148354, AY148358, AY148367, AY148368, AY148369) and three sequences (JQ319035, JQ319036 and JQ319037) were similar (97-99\%) to $H$. latipons. On the basis of the topology of the calculated majority rule, $60 \%$ consensus Maximum Likelihood tree for all the Moroccan populations

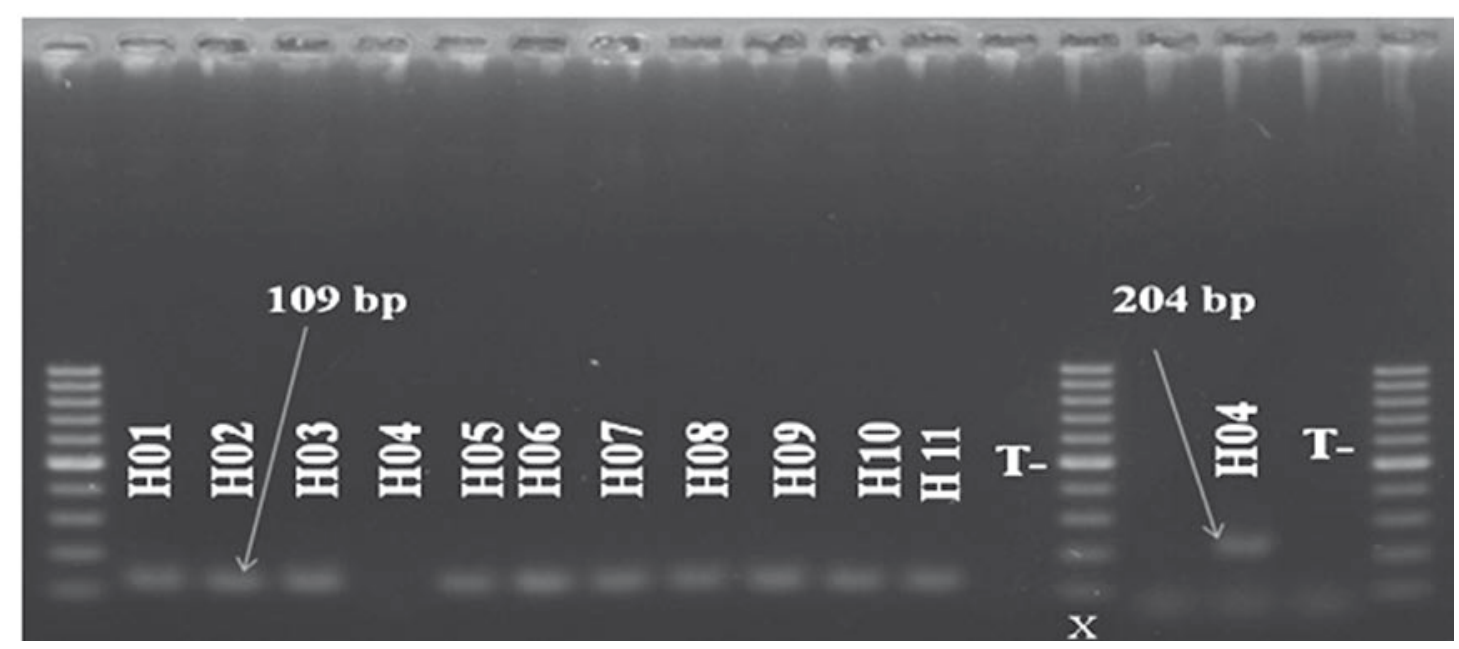

Fig. 1. Results of specific PCR for Heterodera avenae ( $\mathrm{H01}, \mathrm{H} 02, \mathrm{H} 03, \mathrm{H} 05, \mathrm{H} 06, \mathrm{H} 07, \mathrm{H} 08, \mathrm{H} 09, \mathrm{H} 10, \mathrm{H} 11)$ and $H$. latipons (H04). $\mathrm{X}=100$ bp DNA ladder (Promega Benelux). Codes for populations: see Table 1 


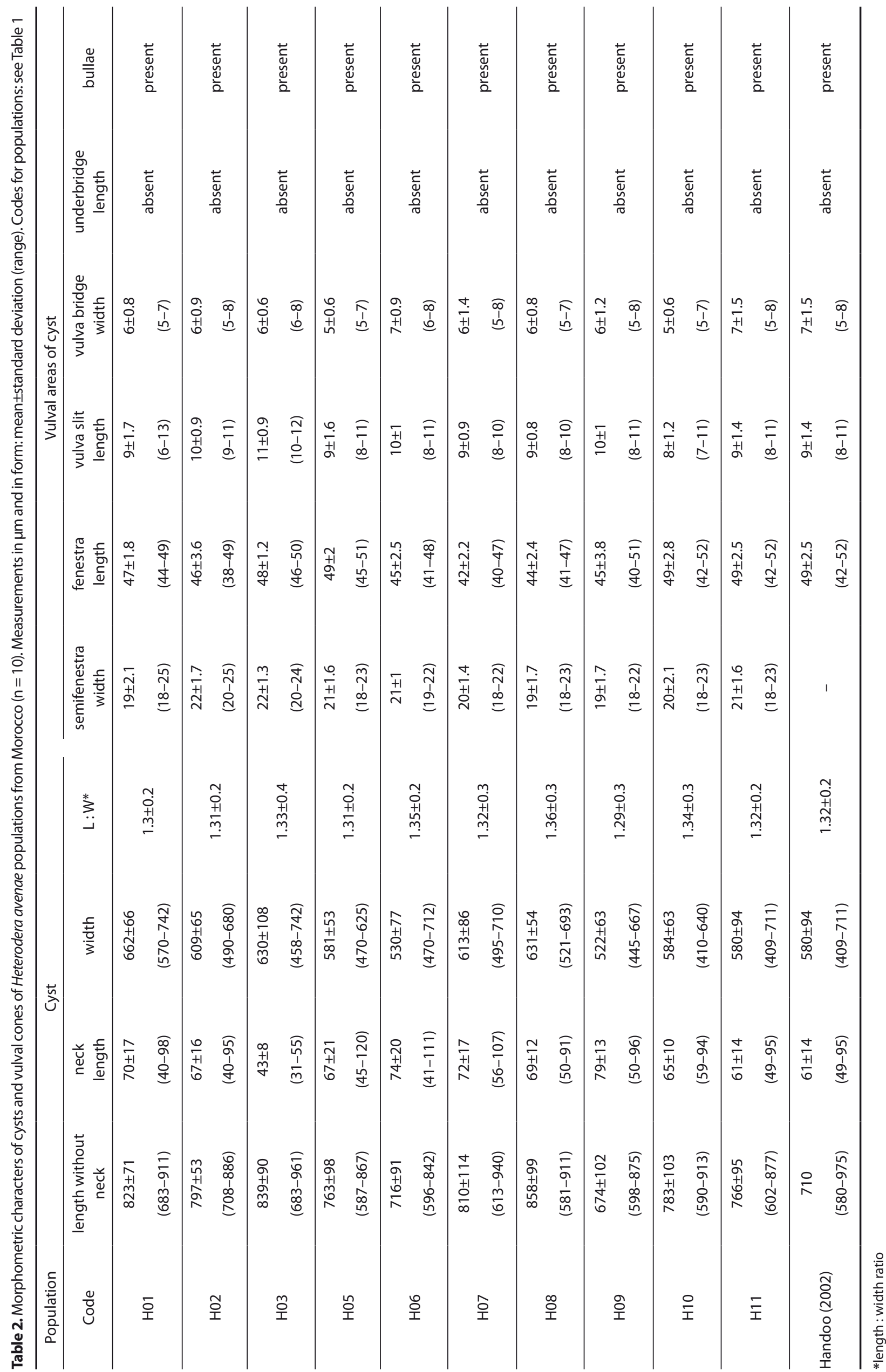




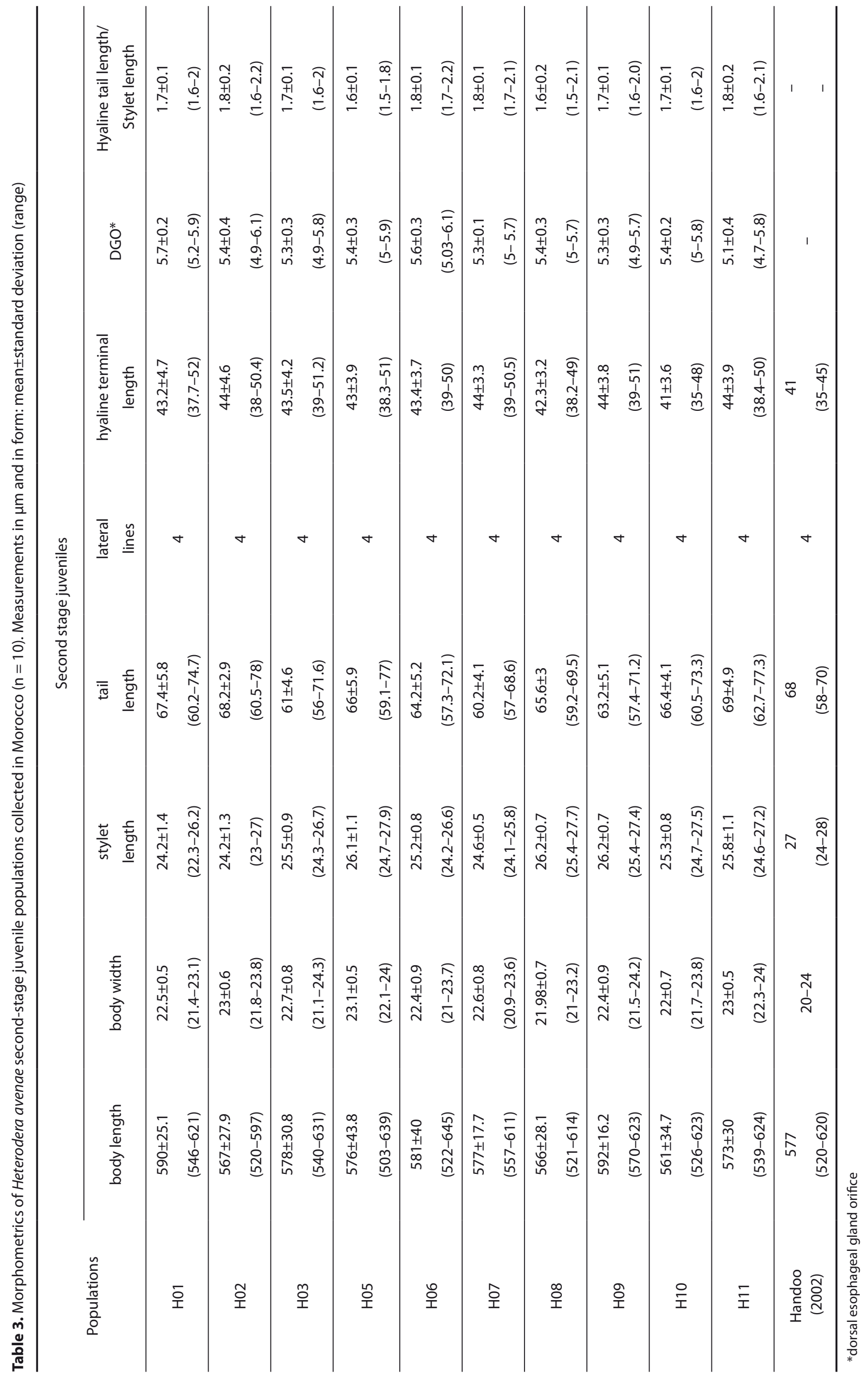




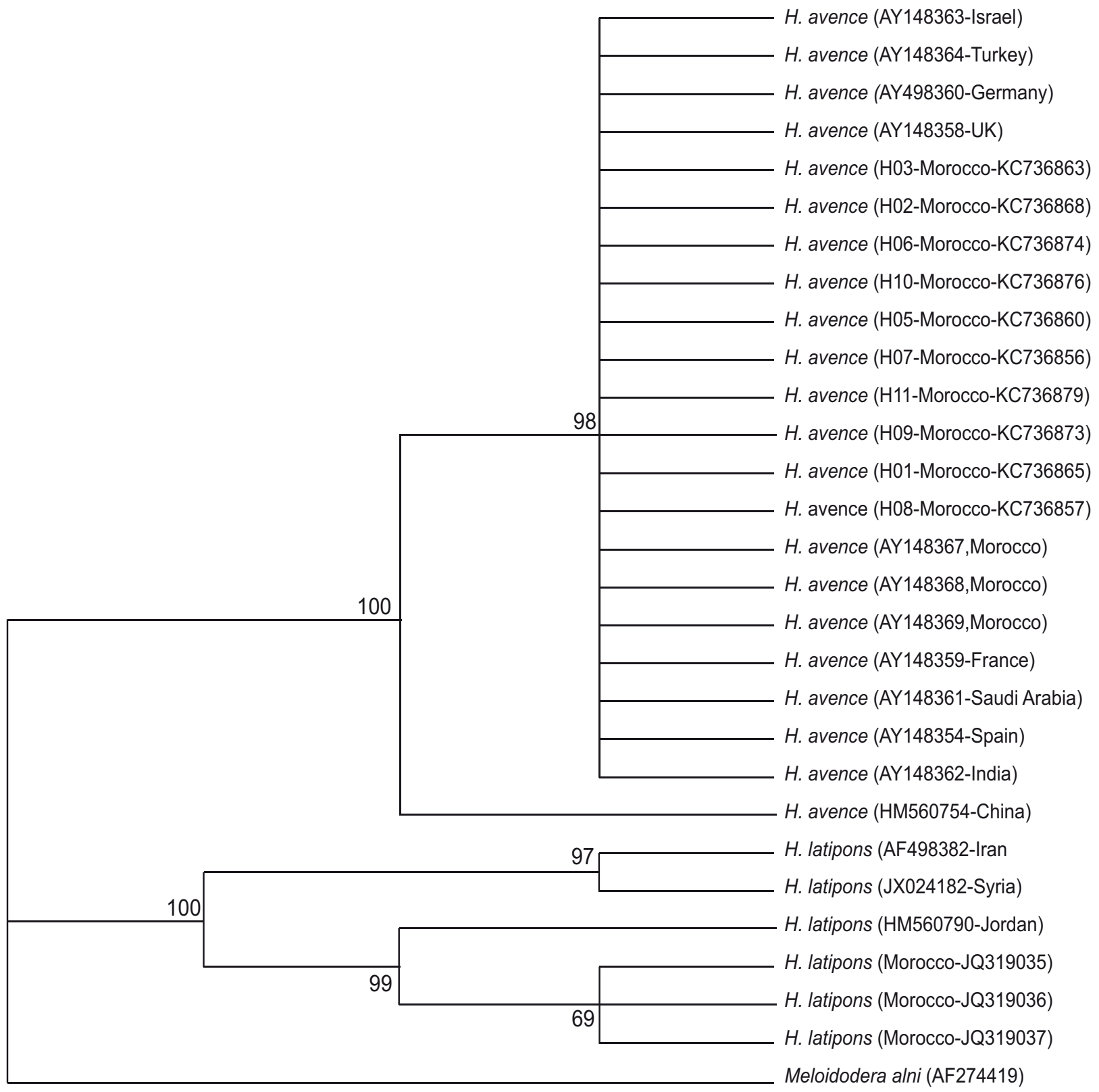

Fig. 2. The topology of the majority rule 60 consensus Maximum Likelihood tree for all populations studied with the addition of Heterodera populations obtained from GenBank based on the sequence alignment of the ITS-rDNA. For the list with the abbreviations of the population codes see Table 1

collected in the survey and the three Moroccon populations in GenBank (AY148367, AY148368, AY148369), Subbotin et al. 2003 and 16 Heterodera spp. from GenBank, two major groups of Heterodera were revealed (Fig. 2).

\section{Discussion}

Two species, viz. $H$. avenae and $H$. latipons were detected during the survey of cyst nematodes in the major cereal-cultivating areas of Morocco. The latter species was detected for the first time in the country; it was found in a wheat field in Ain Jmaa (Saiss) (Mokrini et al. 2012). Previous surveys in the area had revealed the presence of $H$. avenae only (Ammati 1987; Mokrini et al. 2009). In this study, cysts of $H$. avenae were found only in wheat fields (Saiss, Chaouia and Zaers regions of Morocco) with two species of root-lesion nematodes (Pratylenchus penetrans and P. thornei) (Mokrini et al. 2016). However, the absence of cysts in barley fields is probably related to the rotation with vegetables or food legumes, practiced in these fields. Moreover, farmers in the main cereal growing areas of Morocco prefer to grow wheat, so fewer fields of barley were sampled, hence reducing the chances for detecting infestations with cysts. Both species were distinguishable easily on the basis of the cyst morphology. All cysts of $H$. avenae had prominent bullae, but no underbridge; H. latipons, 
however, had a strong underbridge and lacked distinct bullae in the vulval cone. Previous studies (Wouts and Sturhan 1995; Subbotin et al. 2003) reported the same morphological characteristics that separated $H$. avenae from $H$. latipons. Compared to $H$. latipons, $\mathrm{J} 2 \mathrm{~s}$ of $H$. avenae have a longer tail, stylet and hyaline part of tail. Abdollahi (2009) reported that the Indian populations of maize cyst nematodes were identified as $H$. zaea based on morphological and morphometric features.

Species-specific primers for PCR have been developed to complement the traditional species identification of $H$. avenae (Toumi et al. 2013a; Yan et al. 2013) and H. latipons (Toumi et al. 2013b). Several genes were successfully used to identify many species of Heterodera (Subbotin et al. 1999; Yan et al. 2013). When using the species-specific primers developed for both H. avenae and H. latipons (Toumi et al. 2013a, b) we obtained the characteristic bands of $109 \mathrm{bp}$ and 204 bp, respectively, confirming their morphological identification. This confirms the specificity of the primer sets.

In addition to the morphology, morphometric, species-specific primers, the sequence comparison of the ITS region clearly separate the Moroccan $H$. avenae from $H$. latipons. This rDNA region has been commonly used to separate nematodes at the species level, including the genus Heterodera (Subbotin et al. 2003). The results reported here did not show any intraspecific polymorphism between Moroccan populations of $H$. avenae based on the ITS sequences. These results are in agreement with Baklawa et al. (2015) who found that $H$. avenae populations originating from different localities of Egypt clustered together in the same group and had high similarities to each other. However, polymorphism among different populations of both $H$. avenae and $H$. latipons had been reported previously (Subbotin et al. 1999; Madani et al. 2004). In our study, based on data of the ITS region, the Moroccan populations of $H$. avenae clustered with $H$. avenae populations from Europe and Asia. The data also confirmed previous results in the phylogram presented by Madani et al. (2004), in which a Moroccan population of $H$. avenae clustered with populations from France, Turkey and Israel. Moreover, the three $H$. latipons sequences from Morocco obtained from the same population were identical to each other and also to a sequence in GenBank from a H. latipons population from Jordan (HM560790). This is the first report providing the integrated morphometric, morphological and molecular characterization of cereal cyst nematode populations from Morocco. Further investigations are necessary to identify the pathotypes of the $H$. avenae and $H$. latipons populations of the Saiss, Gharb, Chaouia and Zaers regions of Morocco, as well as suitable resistance sources to be used in cereal breeding programmes.

\section{References}

Abdollahi M. 2009. Analysis of cyst and cone top morphometrics of Indian populations of maize cyst nematode. Journal of Plant Protection Research 49 (1): 41-47.

Abidou H., Valette S., Gauthier G.P., Rivoal R., El-Ahmed A., Yahyaoui A. 2005. Molecular polymorphism and morphometrics of species of the Heterodera avenae group in Syria and Turkey. Journal of Nematology 37 (2): 146-154.

Ammati M. 1987. Nematode status on food legumes in Morocco. p. 169-172. In:" Nematodes Parasitic to Cereals and Legumes in Temperate Semi-arid Regions" (M.C. Saxena, R.A. Sikora, J.P. Srivastava, eds.). International Centre for Agricultural Research in the Dry Areas (ICARDA), Aleppo, Syria, 217 pp.

Baklawa M., Niere B., Heuer H., Massoud S. 2015. Characterisation of cereal cyst nematodes in Egypt based on morphometrics, RFLP and rDNA-ITS sequence analyses. Nematology 17 (1): 103-115. DOI: 10.1163/15685411-00002855.

Cobb N.A. 1918. Estimating the nema populations of soil. United States Department of Agriculture (USDA) Technical Circular 1, 48 pp.

Dababat A.A., Imren M., Gul Erginbas O., Ashrafi S., Yavuzaslanoglu E., Toktay T., Pariyar S.H., Elekcioglu H., Morgounov A., Mekete T. 2015. The importance and management strategies of cereal cyst nematodes, Heterodera spp., in Turkey. Euphytica 202 (2): 173-188. DOI: 10.1007/s10681-014-1269-z

Ferris V.R., Ferris J.M., Faghihi J. 1993. Variation in spacer ribosomal DNA in some cyst- forming species of plant parasitic nematodes. Fundamental and Applied Nematology 16 (2): $177-184$.

Ferris V.R., Ferris J.M., Faghini J., Ireholm A. 1994. Comparisons of isolates of Heterodera avenae using 2-D PAGE protein patterns and ribosomal DNA. Journal of Nematology 26 (2): $144-151$

Franklin M.T. 1969. Heterodera latipons n. sp., a cereal cyst nematode from the Mediterranean region. Nematologica 15: 535-542.

Greco N., Volvas N., Troccoli A., Inserra R.N. 2002. The Mediterranean cereal cyst nematode, Heterodera latipons: a menace to cool season cereals of the United States, nematology circular 221. Florida Department of Agriculture and Conservation Services Division of Plant Industry. https://www. freshfromflorida.com/content/download/11005/142321/ nemcirc221.pdf

Hall T.A. 1999. BioEdit: a user-friendly biological sequence alignment editor and analysis program for Windows 95/98/NT. Nucleic Acids Symposium Series 41: 95-98.

Handoo Z.A. 2002. A key and compendium to species of the Heterodera avenae group (Nematoda: Heteroderidae). Journal of Nematology 34 (3): 250-262.

Holgado R., Andersson S., Rowe J.A., Magnus-Son C. 2004. First record of Heterodera filipjevi in Norway. Nematologia Mediterranea 32: 205-211.

Holterman M., van der Wurff A., van den Elsen S., van Megen H., Bongers T., Holovachov O., Bakker J., Helder J. 2006. Phylum-wide analysis of SSU rDNA reveals deep phylogenetic relationships among nematodes and accelerated evolution toward crown clades. Molecular Biology and Evolution 23 (9): 1792-1800. DOI:10.1093/molbev/msl044

Hooper D.J. 1986. Handling, fixing, staining and mounting nematodes. p. 59-80. In: "Laboratory Methods for Work with Plant and Soil Nematodes" (J.F. Southey, ed.). CAB International, London, UK, 569 pp.

Madani M., Vovlas N., Castillo P., Subbotin S.A., Moens M. 2004. Molecular characterization of cyst nematode species (Heterodera spp.) from the Mediterranean basin using RFLPs and sequences of ITS-rDNA. Journal of Phytopathology 152 (4): 229-234. DOI: 10.1111/j.1439-0434.2004.00835.x

Mokrini F., Abbad Andaloussi F., Alaoui Y., Troccoli A. 2009. Importance and distribution of the main cereal nematodes 
in Morocco. p. 45-50. In: Proceedings of the first Workshop of the International Cereal Cyst Nematode Initiative, 21-23 October 2009, Antalya, Turkey.

Mokrini F., Waeyenberge L., Viaene N., Moens M. 2012. First report of the cereal cyst nematode Heterodera latipons on wheat in Morocco. Plant Disease 96 (5): 774. DOI: https:// doi.org/10.1094/PDIS-11-11-0999-PDN

Mokrini F., Abbad Andaloussi F., Waeyenberge L., Viaene N., Moens M. 2016. Diversity of root-lesion nematodes (Pratylenchus spp.) associated with wheat (Triticum aestivum and T. durum) in Morocco. Nematology 18 (7): 781-801. DOI: 10.1163/15685411-00002993

Ritter M. 1982. Importance des nématodes à kystes des céréales. Bulletin OEPP 12 (4): 307-316. DOI: 10.111/j.1365-2338. 1982.tb01807.x.

Rivoal R., Valette S., Bekal S., Gauthier J.P., Yahyaoui A. 2003. Genetic and phenotypic diversity in the graminaceous cyst nematode complex, inferred from PCR-RFLP of ribosomal DNA and morphometric analysis. European Journal of Plant Pathology 109 (3): 227-241. DOI:10.1023/ A:1022838806268

Rumpenhorst H.J., Elekçioğlu I.H., Sturhan D., Öztürk G., Eneli S. 1996. The cereal cyst nematode Heterodera filipjevi (Madzhidov) in Turkey. Nematologia Mediterranea 24 (1): 135-138.

Smiley R.W., Nicol J.N. 2009. Nematodes which challenge global wheat production. p. 171-187. In: "Wheat Science and Trade" (B.F. Carver, ed.). Ames, IA, Wiley Blackwell, 202 pp.

Subbotin S.A., Waeyenberge L., Molokanova I.A., Moens M. 1999. Identification of Heterodera avenae group species by morphometrics and rDNA-RFLPs. Nematology 1 (2): 195-207. DOI: $10.1163 / 156854199508018$

Subbotin S.A., Waeyenberge L., Moens M. 2000. Identification of cyst forming nematodes of the genus Heterodera (Nematoda: Heteroderidae) based on the ribosomal DNA-RFLP. Nematology 2 (2): 153-164. DOI: 10.1163/156854100509042
Subbotin S.A., Sturhan D., Rumpenhorst H.J., Moens M. 2003. Molecular and morphological characterization of the Heterodera avenae species complex (Tylenchida: Heteroderidae). Nematology 5 (4): 515-538. DOI: 10.1163/ 156854103322683247

Thompson J.D., Higgins D.G., Gibson T.J. 1994. CLUSTAL W: improving the sensitivity of progressive multiple sequence alignment through sequence weighting, position-specific gap penalties and weight matrix choice. Nucleic Acids Research 22 (22): 4673-4680. DOI: 10.1093/ nar/22.22.4673

Toumi F., Waeyenberge L., Viaene N., Dababat A., Nicol J.N., Ogbonnaya F., Moens M. 2013a. Development of two species-specific primer sets to detect the cereal cyst nematodes Heterodera avenae and H. filipjevi. European Journal of Plant Pathology 136: 613-624. DOI: 10.1007/s10658013-0192-9

Toumi F., Waeyenberge L., Viaene N., Dababat A., Nicol J.N., Ogbonnaya F., Moens M. 2013b. Development of a species-specific PCR to detect the cereal cyst nematode, Heterodera latipons. Nematology 15 (6): 709-717. DOI: 10.1163/15685411-00002713

Wouts W.M., Sturhan D. 1995. Heterodera aucklandica sp. n. (Nematoda: Heteroderidae) from a New Zealand native grass, with notes on the species of the $H$. avenae group. New Zealand Journal of Zoology 22 (2): 199-207. DOI: http:// dx.doi.org/10.1080/03014223.1995.9518034

Yan G.P., Smiley R.W., Okubara P.A., Skantar A.M. 2013. Species-specific PCR assays for differentiating $H$. filipjevi and H. avenae. Plant Disease 97 (12): 1611-1619. DOI: http:// dx.doi.org/10.1094/PDIS-01-13-0064-RE

Zheng J., Subbotin S.A., Waeyenberge L., Moens M. 2000. Molecular characterisation of Chinese Heterodera glycines and $H$. avenae populations based on RFLPs and sequences of rDNA-ITS regions. Russian Journal of Nematology 8 (2): 109-113. 